\title{
〔Regular Paper
}

\section{Study of a new luminescent method using the thin layer}

\author{
assay apparatus
}

\author{
Toshio Imai, * Mitsutaka Yoshida,* Ikuo Mashimo,** \\ Ikunosuke Sakurabayashi*** and Shin Furiya****
}

\begin{abstract}
SUMMARY
We have developed a new assay apparatus for luminescent reaction, which is composed of a thin layer reaction system. To evaluate the usefulness of the present thin layer assay apparatus, the measurement conditions for CK activity were examined as a model. A new assay model for the $\mathrm{CK}$ activity was established in which $\mathrm{CK}$ activity are determined at a temperature of $25^{\circ} \mathrm{C}$ using a thin membrane containing $50 \mathrm{~mm}$ creatine phosphate, $5 \mathrm{~mm}$ ADP, $40 \mathrm{~mm}$ DTT, $20 \mathrm{~mm}$ $\mathrm{Mg}^{2+}$, 3. $2 \mathrm{mM} \mathrm{AP} \mathrm{AP}_{5}$, and $15 \%$ L-Lase. It allowed quantitative measurement of $\mathrm{CK}$ activity from 0.5 to $250 \mathrm{mU} / \mathrm{ml}$. The accuracy of measurement was relatively high, with $C V$ of $3 \%$ to $5 \%$. As for interference of coexisting components in the serum, neither creatinine nor bilirubin had any effect on the CK activity levels, although the presence of $250 \mathrm{mg} / \mathrm{dl}$ or more of hemoglobin in serum caused errors in the measurement of $\mathrm{CK}$ activity. The present thin layer assay system was found to be a feasible new method for bio- and chemi-luminescent reactions in routine laboratory use.
\end{abstract}

Key words : luminescent method, thin layer assay apparatus, CK activity.

\section{INTRODUCTION}

Much attention has recently been focused on bioand chemi-luminescent reaction-based methods as highly sensitive assay methods for biological components.

Apparatus which can detect luminescent reactions, including the fluorometer, are widely used in various fields. ${ }^{12}$ The complexity of the reaction processes of bio- and chemi-luminescence have, however, precluded in-depth study of these luminescent reactions. Recent reports on the application of luminescent reactions in the assay of biological components have dealt with the determination of hydrogen peroxide produced by various oxidases, ${ }^{2-4)}$ catalytic components in luminescent reactions, ${ }^{5)}$ and with measurement methods using luciferase ${ }^{6-8)}$ and photoprotein. ${ }^{9)}$

Nevertheless, there are few practical luminescent methods available for routine laboratory use and commercially available equipments for luminescent assay are unsuitable for the clinical settings, since they require a large quantity of samples, and the operation procedure is too complicated to maintain

新しい薄膜発光分析法に関する研究

* 今井利夫, 吉田光孝; Department of Biology, Faculty of Science, Toho University.

** 貪下郁雄; Department of Clinical Chemistry, Special Reference Laboratory.

*** 櫻林郁之介; Department of Clinical Pathology, Jichi Medical School.

**** 降矢 震; Department of Clinical Laboratory, Chiba University School Hospital.

Correspondence address : Toshio Imai, Department of Biology, Faculty of Science, Toho University, 2-2-1, Miyama, Funabashi 274, Japan.

(Received February 9, 1989, Accepted January 12, 1990) 
the accuracy and reproducibility of the measurement.

We have previously reported an initial rate integration method $^{10)}$ for measuring creatine kinase (ATP : creatine N-phosphotransferase, EC 2.7.3. 2., CK) activity in human serum which is a luminescent reaction-based method for determining serum components. In an attempt to establish a new luminescent assay method for routine use in clinical laboratory, a thin layer reaction system which does not require an excitation illuminant, was prepared. The porous cloth was stratified onto the reaction system so that samples might be attached to reagents for assay at a constant diffusion rate. Using this system, we constructed a luminescent assay apparatus which allows the detector to be secured closer to the membrane than is possible with cell system apparatus, accordingly enable to increase the efficiency of luminescence detection. The apparatus is referred to as the "thin layer assay apparatus" in this study and we have demonstrated the feasibility of this apparatus for determining serum CK.

\section{EXPERIMENTAL MATERIALS}

Serum samples were obtained from healthy subjects and patients with various diseases.

The reagents used for assays were as follows: adenosine- $5^{\prime}$-triphosphate (ATP) and adenosine$5^{\prime}$-monophosphate (AMP) were purchased from Sigma. Luciferin-luciferase (L-Lase) solution and HEPES buffer ( $\mathrm{pH}$ 7.75) were from Analytical Luminescence Laboratory. Creatine phosphate and adenosine- $5^{\prime}$-diphosphate (ADP) were from Boehringer-Mannheim. Polyester film was from Biomate. Porous cloth was from Fuji Photo Film Co., Ltd. The other reagents were of special grade, and were manufactured by Wako Junyaku Co. Ltd.

\section{EXPERIMENTAL METHODS}

\section{Apparatus for measuring luminescence}

For the measurement of luminescent intensity, Lumicounter-1000 manufactured by Niti-On was used in combination with a newly designed thin layer assay apparatus (Fig. 1).
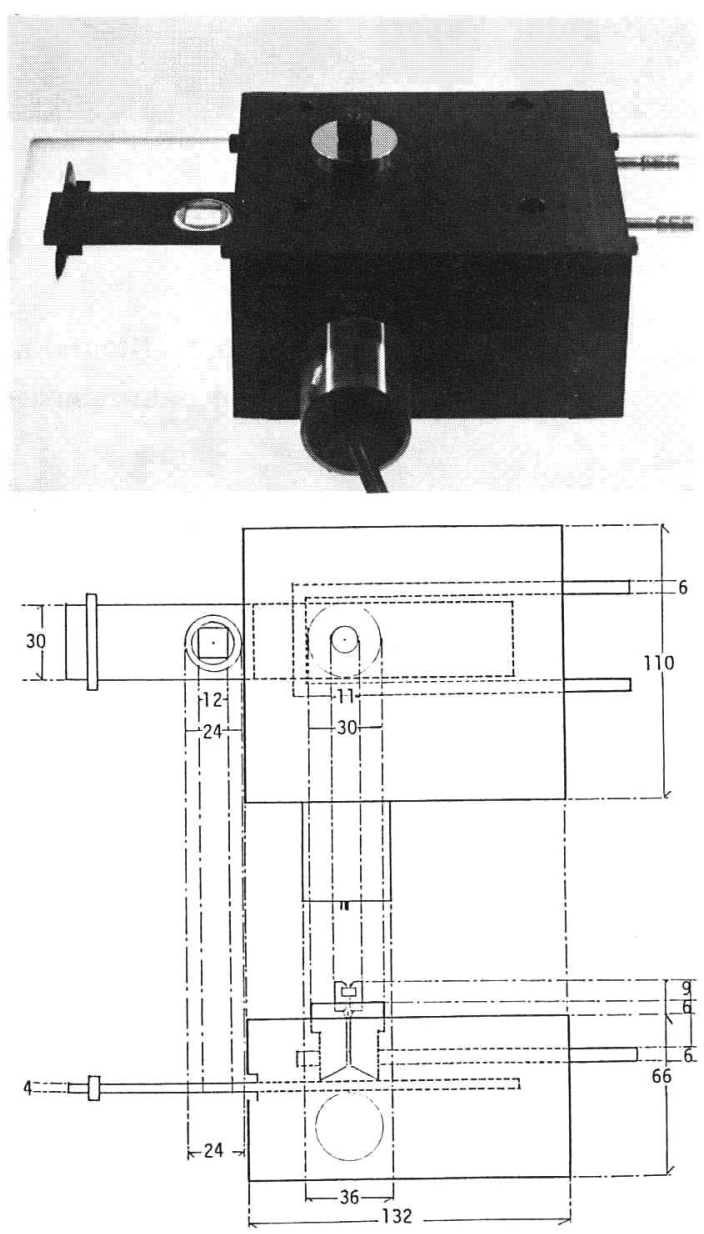

Fig. 1. Thin layer assay apparatus for measurement of luminescence (scale : $\mathrm{mm}$ ).

The reaction system was composed of a polyester film, a gelatin layer, and a porous cloth (spread layer) (Fig. 2).

The gelatin layer was soaked with ATP solution for the measurement of CK activity, and the porous cloth was soaked with substrate for determining enzyme activity. These were placed on the supporting plate drawer (sliding membrane holder). A photomultiplier tube (PMT, Hamamatsu Photonics Co. Ltd., Niti-On) and a reflective mirror were fixed in the lower and upper parts of the reaction system, respectively.

Water $\left(25^{\circ} \mathrm{C}\right)$ was allowed to circulate to maintain constant temperature in the reaction system. Materials were added drop by drop onto the mem- 


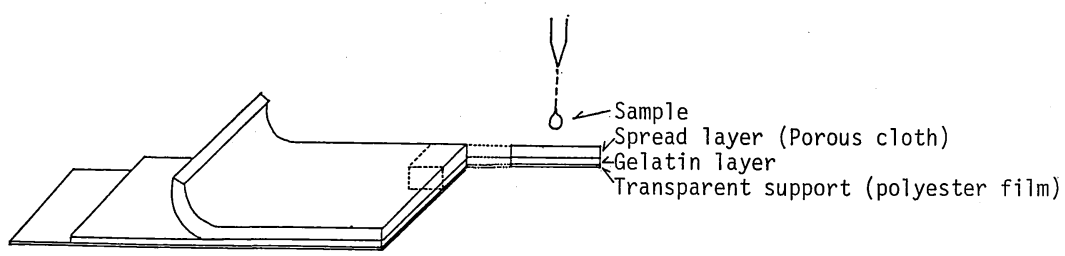

Fig. 2. Schematic structure of the multilayered film for luminescent analysis.

brane with a syringe for assay reaction.

Preparation of gelatin layer containing LLase solution and measurement of the amount of ATP

Gelatin (0.4 mg) was dissolved in $14.3 \mathrm{~mm}$ magnesium sulfate solution $(14 \mathrm{ml})$, to which $2 \mathrm{ml}$ of $2 \%$ hardening solution was added, and $4 \mathrm{ml}$ of $\mathrm{L}$ Lase solution was added to $16 \mathrm{ml}$ of this gelatin solution. The mixture was poured into the acrylic frame $(1.5 \mathrm{ml}$ per $30 \times 30 \mathrm{~mm})$, and was cooled to $4^{\circ} \mathrm{C}$ as quickly as possible for gelation. After complete gelation of the gelatin, the film-like gelatin membrane was cut down to $12 \times 12 \mathrm{~mm}$, and was fixed onto the cell holder for ATP measurement. Simultaneously, a porous cloth was stratified onto the gelatin membrane to obtain satisfactory diffusion.

\section{Measurement of CK activity with the thin layer assay system}

A porous cloth for developing materials $(97 \times 12$ $\mathrm{mm}$ ) was soaked with $500 \mu 1$ of HEPES buffer solution $(\mathrm{pH}=7.75)$, containing $5 \mathrm{~mm} \mathrm{ADP}, 50 \mathrm{~mm}$ creatine phosphate, $40 \mathrm{~mm}$ dithiothreitol (DTT), 20 $\mathrm{mm}$ magnesium acetate, and $3.2 \mathrm{~mm}$ diadenosinepentaphosphate $\left(\mathrm{AP}_{5} \mathrm{P}\right)$.

The cloth was dried in a current of air and cut down to $12 \times 12 \mathrm{~mm}$. It was then stratified onto the gelatin membrane, as indicated in "Measurement of ATP," for assay reaction.

After the gelatin membrane (for the detection of ATP) and the porous cloth (for enzyme reaction) had been secured, in that order, relative to the side of the PMT, to the holder, $10 \mu \mathrm{l}$ of serum was dropped onto the surface of the porous cloth. The changes in the amount of ATP that were produced by $\mathrm{CK}$ reaction were recorded (Fig. 3). One unit of $\mathrm{CK}$ activity was expressed as that which pro-

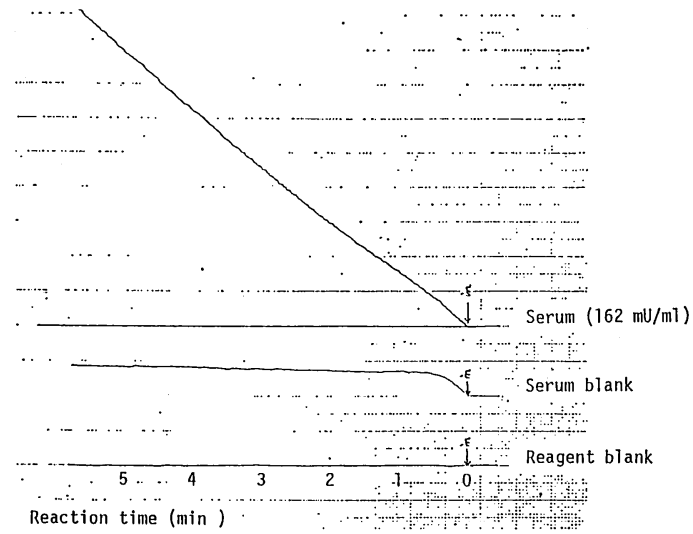

Fig. 3. Time course of $\mathrm{CK}$ reaction by the thin layer assay system.

duced $1 \mu$ mole of ATP at $25^{\circ} \mathrm{C}$ in one minute.

Measurement of CK activity by the ultraviolet absorption method

CK-NAC reagents were supplied by Boehringer Mannheim. Automatic analyzer, Hitachi types $705\left(\mathrm{mU} / \mathrm{ml}, 25^{\circ} \mathrm{C}\right)$ was used for measurement.

\section{EXPERIMENTAL RESULTS}

\section{Conditions for the measurement of ATP} luminescence

(1) Effects of the concentration of L-Lase solution in the gelatin membrane upon the intensity of luminescence

L-Lase solution ranging in concentration from $0.6 \%$ to $20 \%$ was prepared by dissolving gelatin in it. The gelatin solution was poured onto the polyester film to make a film-like gelatin membrane $2 \mathrm{~mm}$ in thickness. As shown in Fig. 4-a, concentrations of L-Lase solution of $10 \%$ or more yielded constant luminescence. Gelatin membrane containing $15 \% \mathrm{~L}$-Lase solution was used for the detection of ATP. 


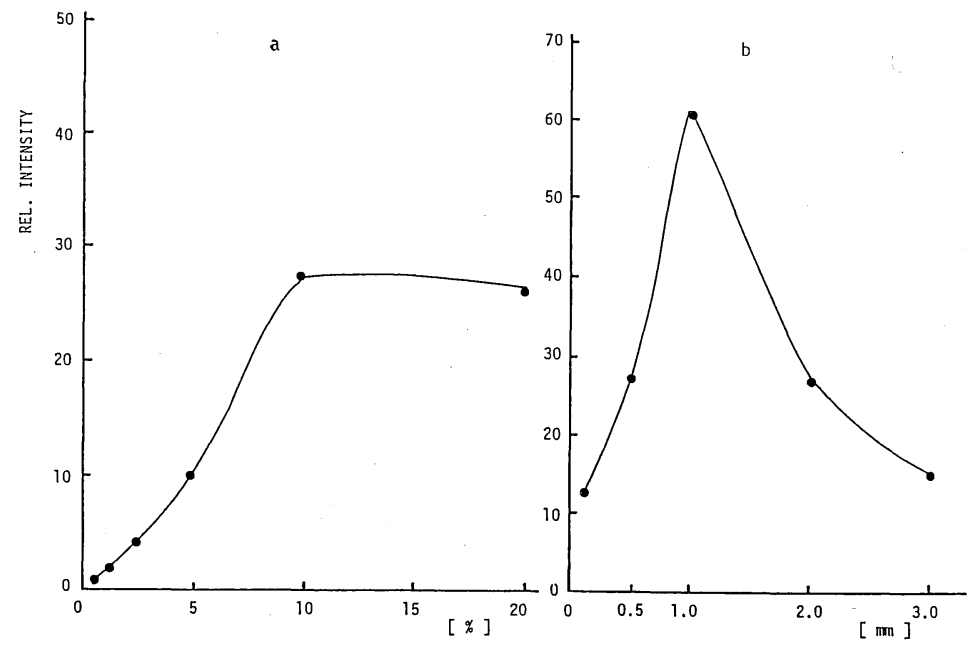

Fig. 4. Conditions for the measurement of ATP luminescence.

a: Effect of luciferin-luciferase concentration on luminescent intensity.

$\mathrm{b}$ : Effect of reaction layer on luminescent intensity.

(2) Effects of the thickness of the gelatin membrane upon the intensity of luminescence

The gelatin solution containing 15\% L-Lase solution was poured into the frame so as to make gelatin membranes ranging in thickness from 0.12 to $3 \mathrm{~mm}$ (corresponding to $2-15 \mu \mathrm{m}$ of film like membrane). The gelatin membrane $1 \mathrm{~mm}$ in thickness yielded the maximum luminescence (Fig. 4b). The intensity of luminescence tended to decrease as the thickness of the gelatin membrane increased. The gelatin membrane $3 \mathrm{~mm}$ in thickness yielded biophasic time course of luminescence, in contrast to the membranes of less than $2 \mathrm{~mm}$ in thickness. Thicker membranes were found unsuitable for the measurement of enzyme activity.

Conditions for the measurement of $\mathrm{CK}$ activity

\section{(1) Effects of concentrations of $A D P$ and creatine phosphate}

The effects of various concentrations of ADP (2.5 to $40 \mathrm{~mm}$ ) upon $\mathrm{CK}$ activity were studied. The maximum CK activity was attained by using $5 \mathrm{~mm}$ $\mathrm{ADP}$ solution. As the concentration of ADP increased, $\mathrm{CK}$ activity tended to decrease.

Study of the effects of various concentrations of creatine phosphate (12.5 to $200 \mathrm{~mm}$ ) upon $\mathrm{CK}$ ac- tivity revealed that a $50 \mathrm{~mm}$ solution gave the maximum level. An increased concentration of creatine phosphate caused a lowering of luminescence as well. Thus, for measuring CK activity, the optimum concentrations of $\mathrm{ADP}$ and creatine phosphate were $5 \mathrm{~mm}$ and $50 \mathrm{mM}$, respectively (Fig. $5-\mathrm{a}, \mathrm{b}$ ).

(2) Effects of concentrations of DTT and magnesium ion

CK activity was examined with varying DTT concentrations from 2.5 to $40 \mathrm{~mm}$. The activity level of CK was approximately 3.5 times higher in the presence of $10 \mathrm{~mm}$ or more DTT than in its absence. Similarly, the addition of $20 \mathrm{~mm}$ or more magnesium ions yielded a 1.5 -fold increase in CK activity relative to when the ions were absent.

The optimum concentrations of DTT and magnesium ion were $10 \mathrm{~mm}$ and $20 \mathrm{~mm}$, respectively (Fig. 5-c, d).

\section{(3) Effects of adenylate kinase on $C K$ activ-} ity, and the efficacy of $A P_{5} P$ addition

The presence of adenylate kinase (AK) in serum causes errors in determination of $\mathrm{CK}$ activity. ${ }^{11)}$ To confirm this, various concentrations of pig AK (muscle) are added to human serum samples. Although $50 \mathrm{IU} / l$ or less of $\mathrm{AK}$ in the serum did not affect $\mathrm{CK}$ activity, there were errors of $50 \%$ in $\mathrm{CK}$ activity measurement in the presence of $100 \mathrm{IU} / \mathrm{l}$ 

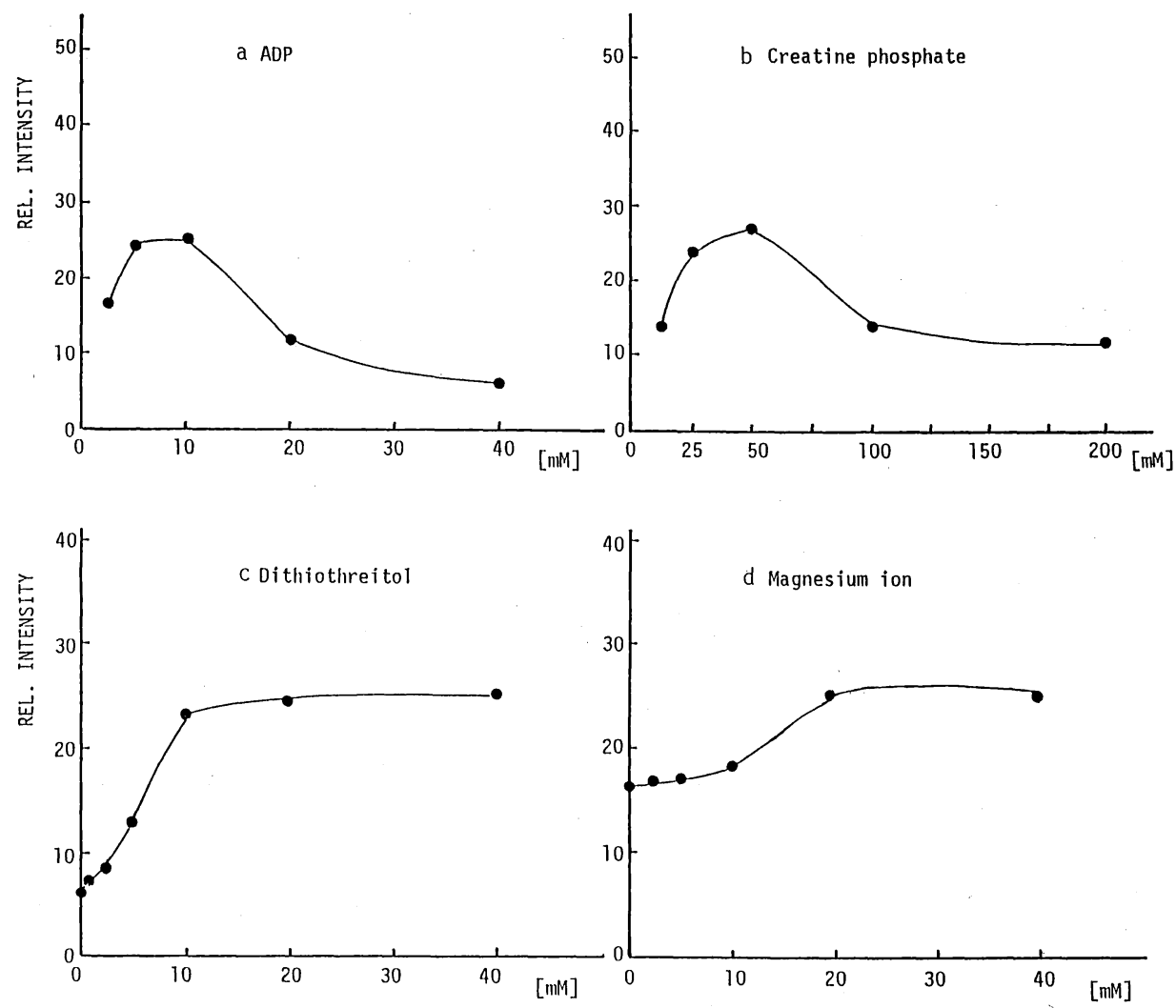

Fig. 5. Effects of concentration of ADP, creatine phosphate, dithiothreitol and magnesium ion.

and errors of $80 \%$ in the presence of $250 \mathrm{IU} / l$. The inhibitory effects of $\mathrm{AP}_{5} \mathrm{P}$, a inhibitor of $\mathrm{AK}$, upon $\mathrm{AK}$ were then examined by adding various concentrations of $\mathrm{AP}_{5} \mathrm{P}$ to the substrate.

The effects of AK $(500 \mathrm{IU} / l)$ were inhibited by $50 \%$ with the addition of $50 \mu \mathrm{M} \mathrm{AP}_{5} \mathrm{P}$ in porous cloth $(97 \times 12 \mathrm{~mm})$ and by $90 \%$ or more with the addition of $3.2 \mathrm{~mm}$ or more. Addition of $3.2 \mathrm{~mm}$ $\mathrm{AP}_{5} \mathrm{P}$ was found to pose no problems in the routine measurement of CK activity.

\section{Calibration curve}

The standard serum level of CK activity was calculated by the standard method recommended by the German Society of Clinical Chemistry. ${ }^{12)}$ To prepare a calibration curve, various $\mathrm{CK}$ activities were obtained by diluting the aforementioned standard serum with $6 \%$ BSA. The present thin layer assay system allowed quantitative measurement of
Table 1. Reproducibility.

\begin{tabular}{cccccc}
\hline \multirow{2}{*}{ No. } & \multicolumn{2}{c}{ Within day } & & \multicolumn{2}{c}{ Day to day } \\
\cline { 2 - 3 } \cline { 5 - 6 } & Normal & Abnormal & & Normal & Abnormal \\
\hline 1 & 72 & 220 & & 67 & 256 \\
2 & 80 & 231 & & 75 & 234 \\
3 & 73 & 243 & & 68 & 257 \\
4 & 70 & 224 & & 65 & 233 \\
5 & 76 & 215 & & 71 & 235 \\
6 & 73 & 238 & & 78 & 232 \\
7 & 79 & 225 & & 74 & 258 \\
8 & 72 & 243 & & 67 & 260 \\
9 & 78 & 225 & & 73 & 238 \\
10 & 77 & 234 & & 72 & 246 \\
\hline $\mathrm{MV}$ (mU/ml) & 75 & 230 & & 70 & 245 \\
$\mathrm{SD}$ & 3.4 & 9.6 & & 3.4 & 11.7 \\
$\mathrm{CV}(\%)$ & 4.6 & 4.2 & & 4.9 & 4.8 \\
\hline
\end{tabular}




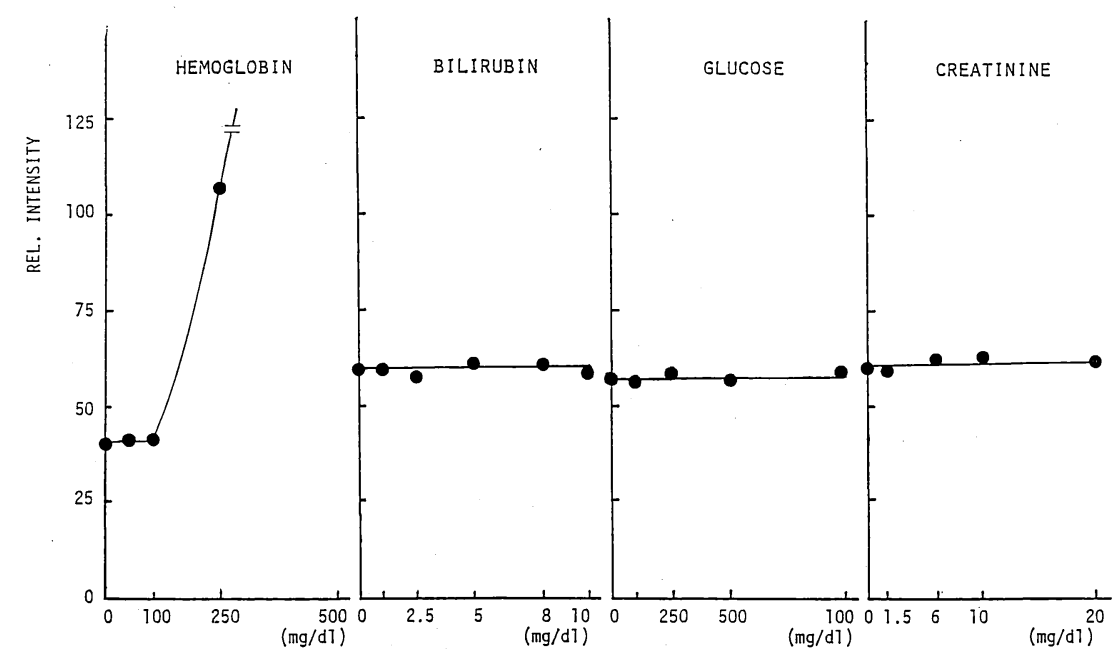

Fig. 6. Effects of various substance on serum creatine kinase activity.

$\mathrm{CK}$ activities ranging from 0.5 to $250 \mathrm{mU} / \mathrm{ml}$.

\section{Reproducibility of the present method}

Both within day and day to day precision were examined by using two human serum samples of different activity. Coefficients of variation $(C V)$ for ten within day precision were $4.2 \%$ and $4.6 \%$, and $C V$ for ten day to day precision were $4.8 \%$ and $4.9 \%$.

The present thin layer assay system was found to be satisfactory for routine laboratory use (Table 1).

\section{Effects of coexisting components of $\mathrm{CK}$ ac- tivity}

Various concentrations of creatinine, bilirubin, and hemoglobin were added to human normal serum samples to examine, by the conventional method, their effects on CK activity.

As shown in Fig. 6, the addition of creatinine, glucose and bilirubin did not have any effect on the $\mathrm{CK}$ activity; nor did hemoglobin interfere with the luminescent reaction at low concentrations. However, the presence of $250 \mathrm{mg} / \mathrm{dl}$ or more of hemoglobin in the serum caused the $\mathrm{CK}$ reaction baseline to increase sharply, making it impossible to measure the reaction rate. Much caution is required in the measurement of $\mathrm{CK}$ activity when extremely hemolytic serum samples are used.

\section{Correlation between thin layer assay method and ultraviolet absorption method}

The correlation between the present thin layer assay system and the method recommended by the German Society of Clinical Chemistry was examined using serum samples obtained from 30 patients with different CK activity levels.

The correlation coefficient was 0.99 (regression line $Y=0.99 X-11.7, Y$; UV method, $X$; present method); showing relatively good correlation at

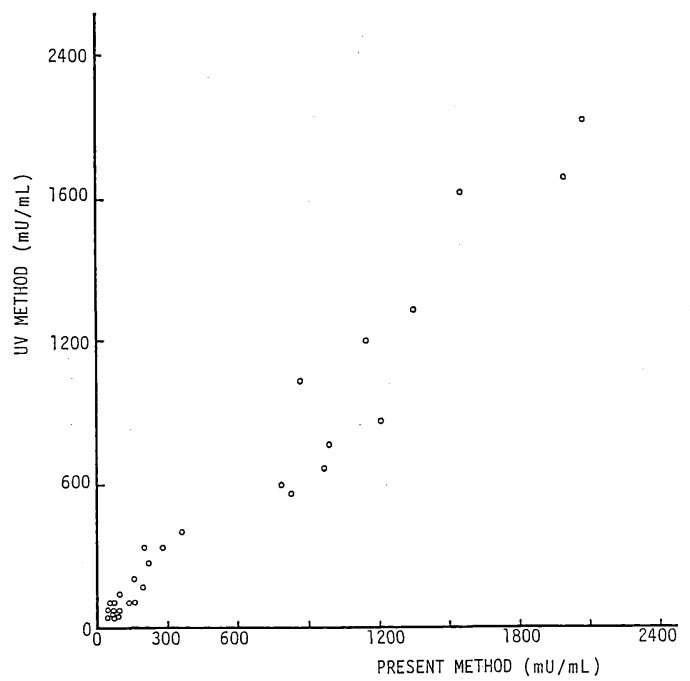

Fig. 7. The correlation between the spectrophotometric and the present methods of total CK activity. 
both high and low CK activity levels (Fig. 7).

\section{DISCUSSION}

The existence of bio- and chemi-luminescence phenomena has long been known. ${ }^{13-15)}$ Many basic studies of these phenomena, including reaction mechanisms, have revealed various characteristics when use is made of the phenomena in assays.

The luminescent reaction have many advantages, including that of enabling the construction of a highly sensitive assay system because of high quantum efficiency, especially in bioluminescent reaction; rapid response, allowing rapid measurement; the lack of need for an excitation illuminant because of emission of luminescence directly as energy of the chemical reaction; the lack of need for selection of wavelengths, and the usage of filters alone in the assay; and wider range of measurement than with conventional assay systems, because of less background noise and uniform components of the excited molecules. Fluorometry ${ }^{1)}$ is widely employed as a high-sensitivity method for body fluid and tissue components.

Much attention has recently been given to the luminescent reaction-based methods as high-sensitivity assay methods. Previous reports have stated that the sensitivity of such methods is 10,000 times higher in measuring $\mathrm{ATP},{ }^{16)}$ and 2, 000 times higher for $\mathrm{NADH},{ }^{17)}$ than conventional fluorometry. More recently, the quantities of the aforementioned components after reaction have been used in enzymatic assays for determining creatine phosphate, ${ }^{18)} \mathrm{c}-\mathrm{AMP},{ }^{19)} \mathrm{RNA}^{20)}$ and Fatty acids ${ }^{21)}$ in the biological samples. However, none of these luminescent reaction-based methods has been widely adopted in routine use. There are many possible reasons for this. First of all, luminescence assay apparatus, which is now commercially available, is used in reactions within a tubular cell system.

In the case of bio- and chemi-luminescent reactions, the intensity of luminescence and the time course of the luminescent reaction occasionally change, depending on the ratio between serum sample and assay reagents and on the proportions of the mixture, as well as the reaction temperature. Strict settings of measurement conditions are required to maintain consistent accuracy of measurement.

We have attempted the application of a new thin layer assay apparatus, developed on the basis of the characteristics of luminescent reaction, in enzymatic assays. The apparatus is composed of a thin gelatin membrane of several microns, which does not require excitation illuminant and allows the mixing of reagents under consistent conditions. The gelatin membrane is soaked with reagents for detection, and the porous cloth is stratified onto it. This makes it possible to attach samples to reagents at a constant diffusion rate.

The present thin layer assay system has the following advantage : the position of the detector can be closer to the apparatus than in the case of a cell system assay apparatus, and the surface area of the reaction system is expandable, making it possible to determine luminescence more efficiently.

When light emitted from the sample is received by the PMT, the number of photons is affected by the geometrically three-dimensional angle dependent on the surface of PMT and the distance between sample and PMT. That is, when the effective surface area of PMT and the distance between PMT and sample are defined as $A$ and as $l$, respectively, coefficient $F$ is $F=A / 4 \pi l^{2}$. This indicates that the distance between the sample and the PMT should be as short as possible.

In the present experimental investigation, the thin layer assay system was used in the determination of CK activity based on the amount of ATP associated with the firefly L-Lase reaction, a representative model system for bio-luminescent reaction, with the purpose of evaluating the usefulness of the assay system. In the clinical diagnosis of myocardial diseases, changes in total $\mathrm{CK}$ activity levels have been determined by various methods, including colorimetry, ${ }^{22)}$ ultraviolet absorption method, ${ }^{23,24)}$ and fluorometry. ${ }^{25,26)}$ In the detection of the causative organs, CK activities have been determined at the isozyme level using electrophoresis with supporting media, ${ }^{27)}$ column chromatography, ${ }^{28)}$ and various assay methods for total activity after the separation of antiserum. ${ }^{29,30)}$ Because 
$\mathrm{MB}$ and $\mathrm{BB}$ isozyme activities are extremely low, a highly sensitive assay method is required to detect their changes.

In this study, CK activities were determined from the varying amounts of ATP produced after enzyme reaction by establishing conditions for ATP measurement and by using ADP and creatine phosphate as substrates.

For measurement conditions of $\mathrm{CK}$ activity, the optimum concentrations of ADP and creatine phosphate were $5 \mathrm{~mm}$ and $50 \mathrm{~mm}$, respectively. However, higher concentration of both substrates exerted an adverse effect on the luminescent reaction. The sensitivity of the present assay system was 0.5 $\mathrm{mU} / \mathrm{ml}$, which is higher than colorimetry. ${ }^{22)} \mathrm{Co}-$ efficients of variation for both within day and day to day assay ranged from 4.2 to $4.9 \%$, similar to those of spectrophotometry. ${ }^{23,24}$ )

The thin layer assay system was found useful in the luminescent reaction, and allows samples and reagents to come in contact at a constant diffusion rate through the thin membrane. Although neither creatinine nor bilirubin in the serum had any effect on the measurement of $\mathrm{CK}$ activity, $250 \mathrm{mg} / \mathrm{dl}$ or more of hemoglobin caused measurement errors. In the measurement of $\mathrm{CK}$ activity, care should be paid to the use of serum samples in which hemolysis is extreme. There was good correlation between the present system and the method recommended by the German Society of Clinical Chemistry $^{12)}(\gamma=0.99)$.

In conclusion, the newly developed thin layer assay apparatus was satisfactory for use in the measurement of amounts of bio- and chemi-luminescence. It was capable of determining serum $\mathrm{CK}$ activity more rapidly and accurately than conventional methods. This system is a promising highsensitivity assay method for biological components, as well as a screening method, since its procedure is more simple than that of the cell system.

\section{ACKNOWLEDGEMENTS}

We thank Mr. Honda, S. (Niti-On) for helpful discussions.

\section{REFERENCES}

1) Udenfriend, S. : Fluorescence Assay in Biology and Medicine, Vol. I, II, Academic Press, New York and London, 1962, 1969.

2) Oyamburo, G. M. et al.: Biochim. Biophys. Acta, $205:$ 190, 1970.

3) Auses, J. P. et al. : Anal. Chem., $47: 244,1975$.

4) Gorus, F. and Schram, E. : Arch. Int. Physiol. Biochem., 85 : 981, 1977.

5) Hoyt, S. D. and Ingle, J. D., Jr. : Anal. Chim. Acta, $87:$ 163, 1976.

6) Lundin, A. et al.: Anal. Biochem., $75: 611$, 1976.

7) Agren, A. et al.: Anal. Biochem., $78: 229$, 1977.

8) Haggerty, L. et al. : Anal. Biochem., 88 ; 162, 1978.

9) Hallett, M.B. and Campbell, A.K.: Nature, $295: 155,1982$.

10) Imai, T. et al.: Physico-Chem. Biol., $27: 151$, 1983.

11) Oliver, I. T. : Biochem. J., 61 : 116, 1955.

12) Recommendation of the German Society for Clinical Chemistry: J. Clin. Chem. Clin. Biochem., $15: 255,1977$.

13) McCapra, F.: Acc. Chem. Res., 9 : 201, 1976.

14) Plant, P. J. et al.: Biochem. Biophys. Res. Commun., 31: 98, 1968.

15) Shevlin, P. B. et al. : J. Org. Chem., $35: 2178$, 1970.

16) Inaba, F.: Kougaku, 12 : 166, 1983.

17) Yabuuchi, M. et al.: Bunseki Kagaku, $34: 6$, 1985.

18) Jabs, C. M. et al. : Clin. Chem., $23: 2254,1977$.

19) Johnson, R. A. et al. : Anal. Biochem., $35: 91$, 1970.

20) Moyer, J. D. et al. : Anal. Biochem., $131:$ 190, 1983.

21) Ulitzur, S. and Hastings, J. W.: Proc. Natl. Acad. Sci. U.S. A., $75: 266,1978$.

22) Hughes, B. P.: Clin. Chim. Acta, $7: 597,1962$.

23) Rosalki, S. B.: J. Lab. Clin. Med., 69:696, 1967.

24) Wilkinson, J.H. and Steciw, B.: Clin. Chem., $16: 370,1970$.

25) Conn, R. B.: Am. J. Clin. Pathol., 46: 177, 1966.

26) Rokos, J. A.S. et al. : Clin. Chem., 18: 193, 1972.

27) Burlina, A.: Clin. Chem., 26 : 317, 1980.

28) Bondar, R. J.L. et al. : Clin. Chem., 26:618, 1980.

29) Obzansky, D. and Lott, J. A. : Clin. Chem., $26: 150,1980$. 
30) Vaidya, H.C. et al. : Clin. Chem., 32: 657, 1986.

\section{要 旨}

発光反応の新しい分析法として反応槽をゼラチンの薄 膜状として検出反応を行う測定装置を開発した．本装置 の有用性を確認するため，モデル系としてクレアチンキ ナーゼ (CK) の活性測定条件について検討し, クレアチ ンリン酸 $50 \mathrm{~mm}$, ADP $5 \mathrm{~mm}, \mathrm{DTT} 40 \mathrm{~mm}, \mathrm{Mg}^{2+} 20$ $\mathrm{mm}$, ジアデノシンペンタホスフェート $3.2 \mathrm{~mm}$ および ルシフェリンールシフェラーゼ $15 \%$ を含む薄膜中で測定
するCK の新しい活性測定条件を確立した。乙の方法を 用いると $0.5 \sim 250 \mathrm{mU} / \mathrm{ml}$ の CK 活性值が定量的に測 定でき測定精度も CV 4.2 4.9\% と比較的優れている ととがわかった，また，血清中の共存成分の影響につい ては，へモグロビンが $250 \mathrm{mg} / \mathrm{d} 1$ 以上共存すると正誤差 を示したが，クレアチニン，グルコースおよびビリルビ ンについては影響が認められなかった，本法は，生物お よび化学発光反応の新しい検出装置として十分応用でき るととが明らかとなった。 